\title{
Still Exploring the Middle Path: a Response to Commentaries
}

\author{
Jane Compson $^{1} \cdot$ Lynette Monteiro $^{2}$
}

Published online: 2 October 2015

(C) Springer Science+Business Media New York 2015

\section{Introduction}

This article is a response to commentaries on our paper (Monteiro et al. 2015) about the relationship between traditional and contemporary mindfulness, or rather Buddhist versus secular mindfulness. In our paper, we focused on the question of ethics (sila), considering questions such as whether ethics teaching is integral to Buddhist mindfulness can be merely implicit in secular mindfulness trainings, or whether it should be expressly taught. We argued for a middle path between these tangled concerns maintaining that the goals and intentions of Buddhist versus secular mindfulness might not be identical but that there are significant areas of overlap, and a healthy and continued dialog between the different streams is mutually beneficial.

Our article prompted many rich and learned responses that have deepened and nuanced the issues. Many authors seemed basically in alignment with our message. Van Gordon et al. (2015), for example, echoed our call that Buddhist and scientific communities work more closely together, and Davis (2015) supported a continued dialog between Buddhist and secular communities about "how it is best for human beings to be." Others gave examples of how Buddhist teachings make helpful contributions to the development and efficacy of secular mindfulness-based interventions (MBIs). Amaro

Jane Compson

jcompson@uw.edu

1 Interdisciplinary Arts and Sciences, University of Washington Tacoma, 1900 Commerce Street, Tacoma, WA 98402, USA

2 Ottawa Mindfulness Clinic, 595 Montreal Road, Suite 301, Ottawa, ON KIK 4L2, Canada
(2015), for example, argued that while Theravada Buddhist teachings do not have a proprietary claim on mindfulness, they nevertheless offer a holistic model for maximizing wellbeing (one that recognizes the importance of the well-being of others) that may be of benefit for developing secular interventions. Amaro (2015), Mikulas (2015), and Greenberg and Mitra (2015) focused on how the different parsings and understandings of the term mindfulness from Buddhist traditions can help secular mindfulness practitioners or teachings become more aware of potential ethical issues.

Taking a different perspective, both Lindahl (2015) and Baer (2015) found merit in the exchange of ideas between Buddhism and secular mindfulness, but both sounded cautionary notes about making untested assumptions that secular mindfulness brings benefits insofar as it is brought into line with the traditional Buddhism. In a similar vein, Baer argued that the key question is not how we can make MBIs more consistent with Buddhism, but how we can maximize their benefits for the broadest spectrum of people, and the way to discover this is through testing available methods and hypotheses through empirical findings and psychological science.

A critique of this kind of position is implied by Grossman (2015) who argued that Buddhist mindfulness is part of an embodied ethic and, in this respect, diverges radically from Western psychology, which tends to focus on cognition in isolation from ethical values. If this is the case, then attempts to fathom Buddhist mindfulness from the perspective of Western psychology are doomed because the lens is not wide enough to view what is being observed - the contours of the model are too tight. In a similar vein, Purser (2015) argued against loosening mindfulness from its Buddhist moorings, suggesting that such a decontextualization is both philosophically and ethically problematic.

In this paper, we engage this area of the discussion about the contextualization of mindfulness within traditional Buddhism. 
In particular, in response to Purser (2015), we explore the question of whether Buddhist teaching, of which mindfulness is a major component, is based on an understanding of a certain lawful structure of reality that exists whether a Buddha (or anybody else) had described it or not, or whether it is a concept that is a cultural invention of the Buddha - a "Buddhist teaching" that is only meaningful in the context of other Buddhist teachings and concepts. This is not a trivial point. If the former is true, then mindfulness and its attendant concepts are something that the Buddha discovered, but did not create, and is no more the property of Buddhism than gravity belongs to Newton. Furthermore, we argue that from the context of the Pali Canon, at least, the dhamma is understood to be ontologically real as opposed to socially constructed. It is part of a phenomenon that is universal, not particular, discovered, not constructed. From this perspective, claims about mindfulness practices being Buddhist ideas co-opted by secular contexts, or of secular mindfulness programs being disingenuously offered as stealth Buddhism to further a religious agenda seem to miss the mark. Such critiques assume that mindfulness practices somehow belong to Buddhism exclusively. However, the critiques of secular Buddhism being stealth Buddhism might make more sense if mindfulness is considered a cultural construction only given meaning and context by the teachings and practices of the historical Buddha and his followers. That is, if the concepts and practices of mindfulness are only meaningful in the context of Buddhist teachings, then attempts to extract them from this context can be seen as denaturing mindfulness, turning it into something entirely different.

As with the original article, we argue that the dichotomous view of mindfulness as either Buddhist or universal is based on certain assumptions that need to be challenged. We argue that reality is always, of course, mediated by foundational assumptions that shape our perception; however, there are ontological constraints that provide criteria for evaluating whether mindfulness (and the attendant other qualities that constitute the Eightfold Path) are right or wrong, skillful or unskillful. In other words, there is a normative reality that the Buddha described, and the truth of this reality is not contingent on whether or not it is described, or by whom. We introduce an analogy of fitness or physical training to explain this model and then apply it to the current debate. We make this claim in the light of our perception of the self-understanding of Buddhist traditions, or at least the ones that we are most familiar with - the Theravada traditions associated with the Pali Canon.

The idea of the lawfulness or natural law of the dhamma is a contentious issue in the current traditional versus contemporary mindfulness debate. The critique has taken at least two forms. The first form is that it is not true that the dhamma is a natural law and that to make this claim is to make a category mistake - instead, it is part of a religion and this is necessarily a cultural, socially constructed reality, categorically different from the truths of the physical-ontological universe. A second kind of critique is that the natural law account is used as a kind of tactical rhetoric to introduce stealth Buddhism into secular contexts. The implication is that sometimes proponents of this model disingenuously present mindfulness and other Buddhist teachings as secular in order to make them more palatable to a secular audience, but that really this is a tactic intended to lure unwitting secularists and believers of other faiths into familiarity with Buddhism.

This constellation of issues is perhaps most clearly demonstrated in Purser's (2015) critique of Monteiro et al. (2015), where we made the case that the Eightfold Path, of which mindfulness is but one limb, refers to a universal cosmic law of nature and is therefore not something that is owned by Buddhists. We comment on this critique, using Purser's challenges as our reference point.

First, Purser accused us of cherry-picking our sources in relation to our understanding of the Pali Nikāyas and that, in contrast to our reading, a true understanding of these would demonstrate that attaining the highest level of realization of the Eightfold Path requires "complete trust in the Buddha, Dharma and Sangha" (via Gethin 1992). This, argued Purser, surely gives lie to the claim that one need not be committed to Buddhist teachings in order to gain this liberation, presumably because he considers that having "complete trust in the Buddha, Dharma, Sangha" is a signifier of being Buddhist insofar as it implies "direct knowledge of, and commitment to, the Buddhist teachings." His argument seems to be that if being committed to Buddhist teaching is thus a prerequisite for liberation, then it cannot be a cosmic universal law of nature - its alleged universality is incompatible with it being only accessible by those with complete trust in the Buddha, Dharma, and Sangha. In other words, this truth is only accessible through the particular route of Buddha, Dharma, and Sangha.

This relates to the second part of his critique, namely that our understanding of the Eightfold Path as describing a causal law that is part of the nature of the universe makes a category mistake. It puts a cultural construction - in this case, Buddhist teachings - in the same category as empirically and publicly demonstrable properties of the physical universe. This helps to elucidate Purser's first critique - if religious doctrines are necessarily always cultural constructions as opposed to, say, the universally accessible reality of the physical universe then, by their very nature, these ideas could never correspond to a cosmic universal law. We address both of these critiques by considering Gethin's (1992) analysis of the presentation of the Eightfold Path in the Pali Canon, using this analysis to argue that the path to liberation identified by the Buddha is considered by him and his followers to correspond to an ontologically real structure of reality. We then discuss the thorny question of whether one has to be Buddhist to be subject to this lawfulness, and discuss some of the implications of this for the current debate about traditional versus contemporary mindfulness. 
In our original article, we argued that "there is no reason in principle why familiarity with explicitly 'Buddhist' teachings are a necessary condition for such liberation." (Monteiro et al. 2015). In support of our claim, we cited Gethin's (1992) careful reading of the Pali Nikāyas and his Eightfold Path is best understood as describing a law of the universe, existing whether anyone describes it or not. This led to our analogy that "this causal law is not an invention of the Buddha or of any other teacher, any more than gravity, for example, was the invention of Newton" (Monteiro et al. 2015). Since much depends on the accuracy of this reading, it is worth unpacking in some detail.

To that end, we summarize Gethin's case. Insofar as the Pali Canon represents a fundamental source of traditional Buddhism, referring to these texts provides a crucial perspective on the traditional versus contemporary debate. Gethin's work on the noble Eightfold Path is very detailed and closely supported; for the purposes of this paper, we will provide a brief overview of the key arguments and passages.

We focus on particular points about the Eightfold Path that are salient to this topic, namely, the fact that the Eightfold Path is presented as the distillation of spiritual practice and as such is uniquely representative of the path of training, the distinction between the factors of the Eightfold Path in their skillful and unskillful aspects, the levels of attainment of the Eightfold Path and the distinction between the ordinary and the noble realization of the eight factors, and the interconnectedness of the eight factors. This will then be related to the different levels of disciple. Having presented the assumption of the ontologically real status of the causality that underpins the path to liberation presented by the Buddha, in the second part of this paper, we discuss the implications of this for the discussion about the relationship between Buddhism and mindfulness.

\section{The Eightfold Path as the Distillation of Spiritual Practice}

In the Pali Canon, the path to liberation - the cessation of suffering - is parsed in multiple ways. Usually, these parsings consist of different lists, such as the seven factors of awakening. Gethin (1992) argued, however, that the Eightfold Path is presented as the distillation of these different practices, which is understood as complete in itself with nothing lacking: "the eight-factored path, as the essence of the spiritual life, acts as a thread that runs through the Nikāyas: 'Formerly and also now, bhikkhus, I make known just suffering and the end of suffering' (M1.140)" (p. 203). Here, as elsewhere, in the Nikāyas, the Eightfold Path is described as the way leading to the cessation of suffering, or the fourth noble truth. It is the way to address the basic problem that Buddhist teachings address: suffering $(d u k k h a)$. Buddhist texts portray suffering as a universal problem, experienced by all sentient beings. Gethin's careful exploration of the Eightfold Path as the distillation of spiritual practice help make the case here that the teachings of the Buddha necessarily imply that there is a certain causal structure to reality, discovered but not created by the Buddha, that make the attainment of goal of liberation from suffering a possibility.

Given its distinct role as the distillation of the spiritual life, it is important to investigate some of the key qualities of the Eightfold Path. The eight factors of the path-the attaigiko maggo - are view, thought, speech, action, livelihood, striving (more commonly translated as effort), mindfulness, and concentration. In its most basic sense, the eightfold categorization describes eight different capacities a person possesses: the capacity for view, thought, speech, action, livelihood, effort, mindfulness, and concentration. Thus, the Eightfold Path is merely descriptive. However, according to the Nikāyas, in order to realize the fourth noble truth and attain the cessation of suffering, a person must transform their conduct and attainment in these eight elements in such a way that they support awakening. This is the Eightfold Path in its prescriptive aspect, and involves, in the first instance, moving from wrong or unskillful to right or skillful practices and, ultimately, to a transformation from ordinary to noble realization of the elements of the path. Right is the common translation of the word samm $\bar{a}$ and each factor of the Eightfold Path can be right or wrong (micchāa). Citing Sumedho, Amaro (2015) explained that right in this context means more than the opposite of wrong, but "rather has a connotation of right as in 'upright', 'balanced', attuned'" (p. 64). This is significant because it frames the ideas of right and wrong in the context of the overall goal of alleviating suffering: "this approach emphasizes the pragmatic consideration 'Does this attitude, this action, alleviate suffering?' rather than the theoretical question, 'Does this experience match the picture of how I believe things to be" (Amaro 2015). Amaro clarified the distinction between kusala and akusala as being determined by the quality of the intention; wholesome or skillful acts are motivated by nonattachment, friendliness, and wisdom; unskillful or unwholesome acts by their opposite qualities - greed, hatred, and delusion (Amaro 2015). Thus, ultimately, the difference between samma and miccha, or kusala and akusala, is that the former of each dyad leads to the ultimate goal of the cessation of suffering, the latter does not. Thus, we might speak of a causality of liberation operating in the context of the Eightfold Path.

The distinction between ordinary and noble is another important one relating to the path as it is presented in the Pali Canon. The Eightfold Path can be practiced and realized in its ordinary (lokiya) aspect but, at a certain level of attainment, is realized in its transcendent (lokuttara) or noble (ariya) aspect. The clearest exposition of this transcendent/ ordinary distinction lies in the Mahacattarisaka Sutta of the Majjhima Nikāya (M 3.71-8; Ñānamoli 1995, pp. 934-40). 
This sutta gives a very useful exposition on the path and the relatedness of the eight different factors, so it will be helpful to undertake a detailed analysis of it. The sutta begins with the Buddha teaching his disciples about "ariyan right concentration," with its supports and equipment. These supports and equipment (sa-upaniso sa-parikkhäro) are the other seven limbs of the path, namely, ariyan right view, thought, speech, action, livelihood, effort, and mindfulness. This suggests that ariyan right concentration exists not on its own, but in connection with, supported and nourished by, the other factors of the path. The same is true of all the other factors of the path.

Throughout the Mahacatarisaka Sutta, there is a strong emphasis on right view. In relation to the supports and equipment of noble right concentration, the Buddha emphasizes that right view is the forerunner of the other elements. In this respect, right view is defined as recognizing wrong view as wrong view and right view as right view. Wrong view is defined as the opinion that " There is nothing given, nothing offered, nothing sacrificed; no fruit or result of good and bad actions; no this world, no other world; no mother, no father; no beings who are reborn spontaneously; no good and virtuous recluses and brahmins in the world who have realized for themselves by direct knowledge and declare this world and the other world.' This is wrong view" (Ñānamoli 1995, p. 934). Wrong view here seems characterized as a kind of nihilism, a denial of cause and effect, and specifically a denial of the possibility that anybody has attained enlightenment. This makes sense in light of the fact that if the causality of liberation were not true, then enlightenment would indeed be impossible.

On the other hand, right view in the sense of distinguishing right from wrong comes first in the context of each factor of the path. For instance, it is right view that recognizes wrong action (i.e., taking life, taking the notgiven and sexual misconduct) as wrong action and right action as right action (M 3.72-3; Ñannamoli 1995, p. 934). In each case, there is a distinction made between two types of right view, that which "is affected by taints, partaking of merit, ripening on the side of attachment"(M 3.72; Ñānamoli 1995, pp. 934-935), and right view that is "noble, taintless, supramundane, a factor of the path." With each section of the path, the same distinction is made between the factor with taints and the noble factor, the component of the way. The taints (äsavas-sometimes translated as corruptions, cankers, or defilements) are attachment to sense pleasures, craving for existence, ignorance, and attachment to views (commentaries only).

As an example of this format, which is the same for all eight factors, let us look at right speech. Right view comes first insofar as it distinguishes wrong speech from right speech. Right speech is twofold - in the first place it is abstaining from wrong speech (i.e., lying, slanderous speech, harsh speech, and gossiping) and this comes under the category of right speech with taints, on the side of merit, leading to rebirth. The second form is right speech that is "noble, taintless, supramundane, a factor of the path" and is characterized as "the desisting from the four kinds of verbal misconduct, the abstaining, refraining, abstinence from them in one whose mind is noble, whose mind is taintless, who possesses the noble path and is developing the noble path" (M 3.74; Nānamamoli 1995, p. 937). After this exposition of the two different sorts of right speech, it is explained how right effort and mindfulness are involved in the cultivation of right speech in addition to right view: "One makes an effort to abandon wrong speech and to enter upon right speech: this is one's right effort. Mindfully one abandons wrong speech, mindfully one enters upon and abides in right speech: this is one's right mindfulness. Thus these three states run and circle around right speech, that is, right view, right effort, and right mindfulness" (M 3.74; Ñāṇamoli 1995, p. 937).

The same formula is followed for each of the eight limbs of the path. Gethin (1992) discussed the interconnectedness of the different elements of the path:

While right view has precedence because of its function of knowing and seeing what is wrong and causing what is right to arise, right view must be supported by right striving and right mindfulness. Thus, right view must in some sense lead the way because it is what 'sees', but three dhammas [things], namely right view, right striving and right mindfulness, continually interact with the other factors in order to promote them in their 'right' aspect (p. 218).

The distinction between the ordinary understanding of the path with taints and the endowment with noble factors is very important, for they are treated as two stages in the attainment of the Eightfold Path. Gethin (1992) summarized this distinction as follows:

First there is the turning away from wrong view, etc., and the turning towards right view, etc. that are of the ordinary skillful variety. Secondly, there is the attainment of right view, etc., as noble, without àsavas [taints], lokuttara [transcendent], a factor of the path. It is precisely this stage that must be understood as sammā-samādhi sa-upaniso sa-parikkhāro [noble right concentration with supports and equipment] (p. 218).

This brief exploration of the difference between the ordinary and noble Eightfold Path shows us that the eight factors of the path are interdependent, and developing one aspect inevitably both depends on and leads to the 
involvement and development of another in a synergistic relationship. Practice in one of the areas leads to nourishment for the development of the others. It also indicates that continued practice and development of the factors of the Eightfold Path leads to the attainment of a level of insight and practice that ultimately will ensure liberation from suffering. Another way to say this is that at a certain point of development, one reaches a tipping point, where ultimately liberation from suffering is guaranteed. At this point, the factors of the path can be said to be developed in their noble (ariyan) or transcendent (lokuttara) aspect. This is supported by the fact that throughout the Pali Canon, people are categorized into different groupings according to their levels of attainment along this path to realization. The basic division is between ordinary people and the noble or ariyan disciple; the former has not yet realized the level of insight, conduct, and meditative practice that amounts to realizing the path in its transcendent, noble aspect. The latter, the noble disciple, has made that realization and thus is on a path that will inevitably result in attainment of enlightenment. Within this grouping of noble disciples, there are four subcategories, determined by the proximity to this attainment. The idea that, at this level, one is inexorably bound for liberation is indicated by the name of the first type of noble disciple, the stream-winner (sotapanna). The imagery is evocative-one has landed in the stream which is flowing inevitably to Nibbana-there is no turning back.

\section{The Ontology of Causation}

What is being described, or rather presupposed, in the Buddha's teaching, is a causal process, a certain structure of reality. There is plenty of evidence for the causality of liberation throughout the Nikāyas. In the following passage from the Anguttara Nikāya, concentration is seen as the causal factor that allows liberating knowledge and insight to arise: “ . . in the absence of right mental concentration and in the case of one not endowed with right mental concentration, the cause is absent for (the production of) the knowledge and insight of things as they really are" (A 3.200; Jayatilleke 1963, p. 420).

It is a law of the world, a fact of life, that insight follows on from concentration: "It is in the nature of things that a person in a state of concentration knows and sees what really is" (A 5.3; Jayatilleke 1963, p. 421). The fact that nonattachment follows automatically from seeing the way things really are also demonstrates this liberative causation: "A person who knows and sees things as they really are need not make an effort of the will, (saying), 'I shall become disinterested'; it is of the nature of things that a person who knows and sees becomes disinterested" (A 5.303; Jayatilleke 1963, p. 421).

The Dhantabhumi Sutta provides some helpful analogies to illustrate the causal law that operates to bring the factors of the path to their positive fruition. The Sutta begins with Prince Jayasena asking one of the Buddha's disciples, Aggivessana, to teach him the Dhamma. Aggivessana declines, because he knows that the Prince will not be able to understand it, and when he is eventually persuaded to teach it, his fears are realized and the Prince fails to understand. When Aggivessana tells this to the Buddha, the Buddha is not surprised:

Aggivessana, how is it possible that Prince Jayasena, living in the midst of sensual pleasures, enjoying sensual pleasures, being devoured by thoughts of sensual pleasures, being consumed by the fever of sensual pleasures, bent on the search for sensual pleasures, could know, see or realize that which must be known through renunciation, seen through renunciation, attained through renunciation, realized through renunciation? That is impossible. (M 3.130; Ñāṇamoli 1995, p. 991).

He illustrates this story with an analogy of two friends who go to a mountain; one climbs to the summit and the other stays at the bottom. When the man on the summit describes the beautiful view that he can see, his friend at the bottom does not believe him and claims that it is impossible that such a view can be seen. In response, the man on the summit leads his skeptical friend up the mountain, and there he sees the view for himself, and explains that "because I was obstructed by this high mountain ... I did not see what was there to be seen." So it is, explains the Buddha, with ariyan right view: "Prince Jayasena is obstructed, hindered, blocked, and enveloped by a still greater mass than this-the mass of ignorance" (M 3.131; Ñānamoli 1995, p. 991).

This simile is important on two levels. First, it demonstrates that although ariyan right view is presented as seeing what is really the case, it is only realized once one's perception is unobstructed by ignorance. Second, it illustrates how this insight is gained from a particular point of vantage that is the culmination of a certain path of practice. Certain conditions must be fulfilled in order to have this insight. Thus, although it is all around him, the ordinary person cannot see the way things really are because his insight is obscured by the mass of ignorance, an ignorance that is a causal result of his immersion in the world of sense pleasures. One cannot simply gain right view at will, for it is the culmination of a course of training. In a further simile, the Buddha likens each stage of the gradual development formula to different stages in the process of taming a wild elephant - the elephant tamer has to work gradually and patiently before the creature is "rid of all faults and defects, purged of all flaws" (M 3.133; Ñāṇamoli 1995, p. 993). 
This idea of the existence of a certain causality of liberation is supported by Gethin (1992) who suggests that both the Eightfold Path and dependent origination are descriptions of a certain law of nature. Gethin noted that, toward the end of the Mahācattarāsìka Sutta, the presentation of the factors of the path bears a significant resemblance to that of dependent origination. The sutta takes its name (i.e., The Great Forty) from the classification of the ten stages of the path (the eight limbs of the Eightfold Path, plus Right Freedom and Right Knowledge which are perfected by the arahat) into $40 \mathrm{sec}-$ tions, 20 concerning wrong elements and 20 concerning right ones. Each element is described along with the states that arise as a consequence of its existence. For example, wrong view is one item on the list, and "those various evil unskilled states that arise conditioned by wrong view" is another (M 3.76; Gethin 1992, p. 220). Each wrong element is described as being worn away by the corresponding right element, which leads to various skillful results. Thus, altogether, there are 40 items. Significantly, the lists of both right and wrong elements begin with view, which set in motion the respective cycles of skillful and unskillful conduct. Gethin pointed out that this treatment of right and wrong view and its relation to the other factors in the Mahācattarāsīka Sutta is echoed in the opening sutta of the magga samyutta:

Ignorance comes first ... in the attaining of unskilful dhammas; after [come] lack of self-respect and disregard for consequence. For one given to ignorance, for one who is ignorant, ... wrong view appears; for one of wrong view, wrong thought ... wrong speech ... wrong action ... wrong livelihood ... wrong striving ... wrong mindfulness ... wrong concentration appears. Knowledge comes first ... in the attaining of skilful dhammas; after [come] self-respect and regard for consequence. For one given to knowledge, for one who has knowledge ... right view appears ... right concentration appears (S v.1-2; Gethin 1992, p. 221).

Gethin (1992) argued that this treatment of the cycles of good and bad conduct resembles the positive and negative cycles of dependent origination insofar as right view is positioned at the beginning of the positive cycle and wrong view at the negative, in the same way as ignorance comes first in the sequence of dependent origination, conditioning the whole cycle of dukkha, and the cessation of ignorance enables this cycle of suffering to cease:

The significance of this is, I think, that we might speak of the law of paticca-samuppāda [dependent origination] in the Nikāyas, and also of the law of the eightfactored path. These are in a sense two aspects of essentially the same thing, namely dhamma. According to early Buddhist literature, the law of pațicca-samuppāda is not something that can be avoided, it is not something that there is any choice about; it is the law of the world and endures whether or not a Tathāgata arises in the world. Either the cycle of paticca-samuppāda will tend towards the accumulation of this mass of dukkha, or it will tend towards its cessation; it cannot be otherwise. The law of the eight-factored path can be understood similarly. The eight factors embrace eight essential aspects of existence - eight aspects that cannot be avoided. As long as these eight aspects are sammā or right they continue to interact properly and move in a skillful direction towards the cessation of dukkha. When they are micchā or wrong they interact wrongly and move away from the cessation of suffering. What ultimately issues from the skillful interaction or cycle is the ariyo atthangiko maggo itself (Gethin 1992, p. 220).

This idea of the Eightfold Path describing an objectively existing causal process has support elsewhere in the Nikāyas. In the Cula-Malunkyavada Suttta, the Buddha tells his student Malunkyaputta that anybody who abandons the five lower fetters (becomes a noble disciple) will have done so through fulfillment of the path: "There is a path, a way to the abandoning of the five lower fetters; that anyone, without coming to that path, to that way, shall know or see or abandon the five lower fetters - this is not possible. Just as when there is a great tree standing possessed of heartwood, it is not possible that anyone shall cut out its heartwood without cutting through its bark and sapwood, so too there is a path ... this is not possible" (Gethin 1992, p. 120).

To summarize, the Eightfold Path describes both a causal process and the fulfillment of this process. It describes a law of nature or a law of the mind that, like dependent origination, operates objectively and is part of the nature of things.

All these factors serve to increase the impression that the Buddha's teaching, the Dhamma, presupposes a certain objective causal structuring of reality. The proximity to liberation of any individual depends on how much they have set this causal process going in a positive direction. All liberated beings will have fulfilled those aspects of discipline and conduct that are epitomized in the Eightfold Path. Another important point to note here is the mutual interdependence of the different aspects of the path; skillful practice in any of them will necessarily, through the operation of underlying causal processes, lead to wholesome development of the other aspects.

This has important implications for the discussion about the role of ethics training in secular mindfulness programs. On this understanding, it seems that skillful development of the faculty of mindfulness will necessarily nourish and support other elements such as right view, right action, right intention, and so on. Conversely, skillful development of right action, right view, and so on will create the supports and conditions for the skillful development of mindfulness. Of course, 
this begs the question of what is right action or intention, for example. As we have seen, at least from the perspective from the Pali Canon, right is that which is grounded in generosity, wisdom, and friendliness and which has the effect of moving someone toward the cessation of suffering. They are right not because they correspond to a Buddhist dogma, but because they catalyze further development of skillful practices and the abandonment of unskillful practices, with skillful being defined as that which leads toward the cessation of suffering. That this ultimate goal is prized and championed by Buddhist teachings does not mean that it is exclusive to Buddhism, or that it is a creation of Buddhist traditions. The Buddha was quite clear that this process of cause and effect exists whether or not anybody describes it. That it is possible for a non-Buddhist to access this goal is demonstrated by the fact that the ascetic Gotama was not a Buddhist. According to Buddhist traditions, there are three categories of Buddha: a sammā-sambuddha, a sāvaka-buddha, and a paccekabuddha. A sammā-sambuddha or perfectly awakened Buddha is one who, like the historical Buddha Gotama, finds his own path to the cessation of suffering and teaches it to others. A sâvaka-buddha or one who has awakened as a disciple has become enlightened after following the teachings of an enlightened one. The paccekabuddha or silent Buddha also finds his own way to enlightenment (without being taught by a Buddha), but does not teach the path to others (Gethin 1998). This is significant because in these categories of Buddha, the attainment of liberation is possible without familiarity with explicitly Buddhist teachings, because part of the very definition of a sammā-sambuddha or a pacceka-buddha is that there were no existing teachings for them to follow.

Perhaps an analogy would help to illustrate this point. Anybody who is physically fit will have an efficient cardiovascular system and stronger muscles as a result of carrying out a certain course of exercise. It is a law of nature that this is so and that all the different elements of fitness are closely interrelated. For example, one cannot increase the efficiency of one's heart without increasing the strength or efficiency of certain muscle groups, as it is by means of exercising these muscle groups that the heart grows stronger. Similarly, a stronger, more efficient heart leads to more effective oxygen distribution; all the factors of fitness are interrelated, and it is a law of nature that this is so. An analogous situation occurs with the spiritual development epitomized in the Eightfold Path. It is in the nature of things that certain conduct will lead to certain specific results and that the development of one aspect leads to the development of another. Furthermore, and relevant to the point of universality, one may by one's own circumstances attain this level of fitness, for example as a farmer or a construction worker, without ever having heard of or learned fitness routines.

\section{Cosmic Eternal Laws or Culturally Determined Human Values?}

In his response to our earlier article, Purser (2015) argued, "the premise that the specifics of the Eightfold Path factors are eternal, universal or cosmic laws operating on human beings in a similar fashion as gravity causes an apple to fall from a tree is to commit a category error" (p. 27). He went on to elaborate on this distinction:

Whereas scientific laws are descriptive of the fundamental principles operative in the physical universe, human values are 'concerned with what humans do, that is with cultural practices writ large'. The Eightfold Path is both a religious and cultural practice that exists in a completely different domain than gravity, physics and mathematics (p. 27).

Purser seems to imply a hierarchy, or at least a duality, of truths here: those noncultural beliefs that are amenable to scientific explanation and publicly demonstrable versus those that are culturally determined human values and endeavors. Quite what Purser meant by his claim that "science and its natural laws are not a cultural enterprise" is somewhat unclear. This statement is all the more puzzling in the light of his criticism of our alleged "scientism" where he accuses us of showing a "naïve belief in the unassailable authority of science and the logic derived from it." This is puzzling because here it is Purser who implies that the "really real" is that which is discovered by science and that everything else is a "cultural practice." Is he arguing that what differentiates science from other cultural enterprises is that scientific truths are somehow underwritten by the fabric or reality while other truth-claims are socially constructed cultural artifacts? In so doing, he apparently exemplifies the very scientism that he later decries. Another irony is that in arguing that the Eightfold Path is not descriptive of fundamental principles, Purser has radically departed from the core claims of Buddhist traditions in the cause of supposedly defending their integrity. Soteriology and ontology are inextricably linked in Buddhist self-understandings. It is precisely the ontological claim that the dharma describes a certain objectively existing universal law of cause and effect that make it accessible to others, whether or not they self-identify as Buddhist. To deny these ontological claims is hardly to defend Buddhism; on the contrary, it is to undermine its self-understanding.

It is perhaps easier to understand the claim that natural laws are not cultural enterprises in the sense that whichever cultural narrative one uses to understand gravity, for example, one is still subject to its force. Is it the case, though, that the only ontologically real (as opposed to culturally constructed) things are those that are scientifically and publicly demonstrable? It is not clear what Purser means by scientifically and publicly 
demonstrable. What counts as scientific? Even if we were to establish a clear criteria for this-for example, that a proposition is empirically verifiable or falsifiable - why does it follow that this is the test for whether or not something is real? How is thought publicly and scientifically demonstrable? Love? What would it mean to empirically verify or falsify these phenomena? If there is not a clear answer to this question, does it therefore follow that these phenomena are not real? To come to this conclusion is problematic not least because, as Wallace (2007) pointed out in his critique of the dogma of scientific materialism, "strictly speaking, there is no objective, scientific evidence even for the existence of subjective experience" (p. 39 ; italics in the original).

Space does not permit a fuller discussion of these ideas, but suffice it to say that some of the assumptions in Purser's critique are problematic. Even if we were to grant that for something to be more than just a culturally determined human value and endeavor, its existence needs to be scientifically demonstrable, one could make the case that, in fact, the law of the Eightfold Path is, at least in some senses, amenable to such scrutiny. We have seen how the goal of the Buddhist training is the reduction and ultimate cessation of suffering; it could be argued that the scientific study of mindfulness does provide many scientifically demonstrable examples of the practice of mindfulness being associated with the reduction of suffering, assuming that we understand stress, anxiety, pain, and so on, as forms of suffering. This may partly explain the enthusiastic embracing of dialog between scientists and contemplatives.

\section{Identity Crises in Secular Mindfulness}

Purser (2015) argued that the mindfulness-based stress reduction (MBSR) community appears to be at risk of an identity crisis. At times, it presents itself as wholly secular and contemporary and, at other times, as a faithful "recontextualization of the dharma" (Purser 2015, p. 24). Before delving deeper into this issue, it is worth sounding a cautionary note against assuming that the secular mindfulness community or even specific subsets of it are monolithic; such variation in approaches might not imply an identity crisis, but rather reflect a spectrum of approaches within rapidly evolving and diverse communities working with mindfulness-based interventions. Another important question that will be considered here is whether being wholly secular and contemporary is not compatible with a faithful recontextualization of the dharma. This brings into focus the validity of the conceptual dichotomy between religious and secular.

First, though, let us consider Purser's argument. He expressed consternation at what he sees as a kind of doublespeak. For example, on the one hand, the Center for
Mindfulness states an expectation that MBSR teachers "be a committed student of the dharma, as it is expressed both within the Buddhist meditations and in more mainstream and universal contexts exemplified by MBSR" (p. 24), and yet on the other hand, it makes the statement that, "This has nothing to do with being Buddhist" (Center for Mindfulness 2014, cited in Purser 2015, p. 24; this reference is no longer available on the CFM website; however, the quote can be found in KabatZinn (1994)). Dharma has both a descriptive and prescriptive connotation - it is used to describe the way things are and also the teachings that lead ultimately to liberation from suffering. Dharma can be understood as describing the fundamental structure of reality that includes causality such that certain conduct and behaviors lead to the alleviation of suffering, and others intensify it. One who investigates and experiments with this causal structure of reality in terms of their own conduct can be described as being a committed student of the Dharma, as could someone who uses Buddhist trainingsDharma in the prescriptive sense - to facilitate this exploration. This issue is complicated, of course, by the question of what being Buddhist is understood to mean, but the Center for Mindfulness statement above appears to be arguing that the Dharma and Buddhism are not necessarily identical. What the Buddha offers is a comprehensive path or a course of training that facilitates this exploration and brings it to fruition as expeditiously as possible. In the Pali Canon, when comparing his dharma and discipline to those from other schools and traditions, the Buddha did not claim exclusive access to The Truth but was unequivocal in his claims that his course of training was the best, the most effective, the most efficient in realizing the goal of "cessation, tranquility, realization, enlightenment Nibbana": "If anyone were to refer to any holy life as being fully successful and perfect, with nothing lacking and nothing superfluous, well-proclaimed in the perfection of its purity, it would be this holy life they would be describing" (D3 126; Walshe 1995, p. 431). The fundamental causal structure of reality, though, operates whether one follows Buddhist teachings or not. In this sense, investigation of one's relationship to suffering is, indeed, nothing to do with being Buddhist. One can investigate it through different media and programs; Buddhist paths are just one option; albeit according to Pali Canon, the Buddha's dharma is the most effective path to achieving the goal of the cessation of suffering.

Let us return to the analogy of physical fitness. Suppose that one's goal is a particular level of accomplishment and fitness - let's say, for example, the ability to run 26.2 miles without stopping - and still be an uninjured healthy person by the end of it. Somebody committed to this goal might choose to train for it on his or her own, or they might train following a particular regimen or with a certain group; they would have a bewildering array of options to choose from in this regard. Each of these options offers different techniques, exercises, and nutrition plans, but each is designed to accomplish the 
same goal. It may be that some of these programs are much more effective than some others. What differentiates the effective ones from the ineffective is the extent to which work-in other words, when followed, how reliably they lead to successful accomplishment of the goal. For such a program to work, it must mesh correctly with a certain causal lawfulness of reality. These are laws that govern such things as how to improve aerobic capacity, how to build strength and stamina, how much time muscles need to recover, how much impact our bones and tendons can tolerate, and how much energy and hydration that a body needs to be sustained on a long run. None of these laws are invented by, much less owned by, the designers of a marathon training program. However, a good training program is based on an excellent understanding of these laws and also on tried and tested practices that take them into account and have been shown to be successful. One does not have to be an athlete in order to be subject to these causal laws any more than one has to be a Buddhist to be subject to the causality of liberation. Choosing to undertake marathon training does not equate to subscribing to causal laws that one's running coach has invented. Rather, it means following a regimen that has been discovered and honed by those with more experience who have learned to operate within the laws of cause and effect to gain the best results.

Of course, not everybody has the goal of wanting to run a marathon. Perhaps all one wants is to be able to walk a flight of stairs without being so out of breath, or to be able to run $5 \mathrm{~km}$ without stopping. In this case, one wouldn't undertake the rigorous training of the marathon runner; however modest or ambitious one's goals may be, though, one is still subject to the laws of cause and effect in relation to the development of physical fitness. It is still the case that certain patterns of training will help one achieve one's goals, and that some such training programs will be better than others, and that this is the result of the basic lawfulness and structure of our physical reality. Based on what we have seen about the law of the Eightfold Path and the causality of liberation, it seems clear that the Buddha thought the lawfulness of reality, including dependent origination and the law of the eight-factored path, exists whether or not anybody recognizes it. From the perspective of traditional Buddhism, what makes a Buddha fully awakened is that he has a full and complete understanding of this causal law, and this understanding has led to knowledge and conduct that culminates in the cessation of suffering. The following passage from the Samyutta Nikāya illustrates this point:

Whether there is an arising of Tathāgatas or no arising of Tathāgatas, that element still persists, the stableness of the Dhamma, the fixed course of the Dhamma, specific conditionality. A Tathāgata awakens to this and breaks through to it. Having done so, he explains it, teaches it, proclaims it, establishes it, discloses it, analyses it, elucidates it (S 2.25; Bodhi 2000, p. 551).
What is particularly telling here is the idea that this lawfulness exists whether or not a Tathāgata (a Buddha) exists to fully understand it or not. It is something a Buddha discovers, but not creates. From the perspective of the Pali Canon, it seems that the entire intelligibility of the Buddha's teaching is premised on the idea that there is a certain lawful structure of reality that exists independently of cultural, human endeavors, and that this causality is universally in operation. This is precisely the opposite of Purser's claim that Buddhist teachings are merely cultural constructions that have no universal applicability.

\section{On Being Buddhist}

On this understanding of the law of the Eightfold Path, what does it mean to be Buddhist? The first thing to note here is that the very categories of Buddhism and Buddhist are part of a relatively modern, Western discourse that the Buddha and his followers for much of human history would not have been familiar with. Similarly, the concept of religion which is in opposition to secular life would have been entirely alien to them. Scholars like Smith (1978) and, more recently, Masuzawa (2005), explained how the construct of Buddhism as a distinct religion, separate and distinct from other religious traditions, is a nineteenth century European invention, imposed on what had been hitherto disparate phenomena. The term Buddhism or a direct equivalent is not found anywhere in the Nikāyas. Indeed, Smith pointed out that the earliest use of the term is found in the West when in 1801 Isaac Schmidt wrote about Boudhism (Smith 1978, p. 61). The introduction of all religious "isms" came in the nineteenth century when religion became reified as a concept. However, when one tries to identify exactly what Buddhism is, then it is virtually impossible to define an essence, for the term could refer to the many different forms of the tradition, to all the lives of people who have lived under the name of Buddhism, to the history of the tradition, and to the personal unseen faith that prompts an individual's conduct. Similarly, we cannot be guided by Buddhist's own selfdefinition: "We cannot decide to call Buddhism whatever the Buddhists themselves have called that for, as we have seen, they have been innocent of such a concept" (Gethin 1992, p. 48). A similar point is made by Cabezón (1995) in his discussion of the discipline of Buddhist studies:

Buddhism is itself an artificial construct whose apparent unity and solidity begins to crumble almost immediately upon analysis. Is Buddhism text-based doctrine or behavior-based praxis? Is it what the clergy does or what lay people do? What was done then or what is done now? What happens in Tibet or Japan? Of course, it is all of these things, but that is tantamount to admitting the multivalent character of our subject matter. To say that 
we all work on Buddhism is not to point the finger at similarity but at difference (p. 240).

Taking up this point in the present, Gombrich (2006) explained that for an Indian Buddhist, religion means something different to what it might perhaps mean for a British Christian. For example, in Anglo-American culture, the concept of God seems inextricably linked with our notion of religion. For an Asian Buddhist, however, it might be that he or she sees gods as having nothing to do with religion, but just as part and parcel of a superhuman power structure: "For Buddhists, religion is purely a matter of understanding, and practicing the Dhamma, understanding and practice which constitute progress towards salvation. They conceive salvation - or liberation to use a more Indian term - as the total eradication of greed, hatred or delusion. To attain it is open to any human being ..." (p. 23).

These points are relevant for the present discussion because another area of contention in the traditional/contemporary debate surrounds the idea of secular versus religious and around the idea of what it means to be Buddhist. Is mindfulness really stealth Buddhism? What does Buddhism mean in such a claim? What does it mean to identify a practice (such as mindfulness) as Buddhist, and at what point does it become so decontextualized or demythologized that it is not Buddhist anymore? Who decides what authentically Buddhist means anyway, and what would be the criteria for such authenticity? These are very complex and involved questions well beyond the remit of this paper. However, we mention them here as a cautionary note against essentializing definitions of secular and religious and assuming that all participants in the debate have a shared understanding of these concepts. Even the question "Is mindfulness Buddhist?" carries with it loaded assumptions implying an essentialist understanding of Buddhism as a monolithic entity.

Purser (2015) associated our claims about lawfulness not with the Pali Canon (where they have foundation), but with statements made by Kabat-Zinn (2013), like the following:

The Buddha wasn't a Buddhist ... we turn the Buddha into some big thing. But his fundamental teaching, you can think of him as more as a scientist, like a Galileo or an Einstein - with very deep insight into the nature of his own experience. So from the point of view of mindfulness, and although it is spoken of as the heart of Buddhist meditation, it's about paying attention. How Buddhist is that? It's about awareness. How Buddhist is that? It's about loving-kindness, how Buddhist is that? Or compassion? (cited in Purser 2015, p. 28).

This position incites Purser, referencing also the work of Wilson (2014), to his second kind of critique, namely, that this amounts to a rhetorical strategy of cultural appropriation of Buddhism, repackaging it and purging it of overtly Buddhist references to make it more marketable to Western audiences: "When Kabat-Zinn speaks of mindfulness-based stress reduction he in fact means Buddhist-based (or at least DharmaBased) Stress Reduction, given this intended double definition of mindfulness" (Wilson 2014, p. 89; italics in original). For Wilson, this is a sign of the cultural appropriation of Buddhism; for Purser, this kind of rhetorical strategy is ethically problematic: "If service users, especially those in healthcare settings, are really being taught a form of 'stealth Buddhism', that's an ethical issue. Trying to have it both ways is both problematic and disingenuous" (Purser 2015, p. 26). He maintains that this issue is ethically problematic because, among other things, it potentially violates informed consent rules:

The camouflage tactic of promoting contemporary mindfulness as exclusively and purely secular and scientifically based is used to appeal to a segment of the population [that] would consider Buddhism incompatible or even a threat to their own religious beliefs. This failure of full disclosure may fall short of meeting the standards of informed consent, which legally and ethically requires whether a treatment may, according to attorney Richard Steinecke, "offend a religious, ethical or personal belief of the patient" (Brown 2013, p. 208; Purser 2015, p. 26).

Such critiques only work if one assumes that the dhamma is identical with Buddhism. We have already seen that a reified, monolithic concept-entity called Buddhism is elusive to the extent of being fictional, a relatively recent cultural construction that seeks also to separate the religious from the secular. What is the Buddhism that is being stealthily introduced? Kabat-Zinn (2013) takes a pragmatic approach: MBSR is intended to help with the alleviation of suffering, following universal laws that the Buddha described but are not the exclusive property of Buddhism. MBSR is but one cultural iteration of this dhamma; monastic Theravāda Buddhism, for example, is another; MBSR is only stealth Buddhism if the dharma and Buddhism are understood as identical (see Cullen 2011, for a fuller discussion of this issue).

In the following quote, Wilson (2014) explained more about his misgivings:

As we've seen, religion and values are downplayed by mindfulness authors to garner large audiences-but in many cases, the reason they want an audience in the first place is because they are convinced that mindfulness and other elements derived from Buddhism have a real ability to alleviate suffering (the goal of religious Buddhism) ... Mindfulness is connected to a whole set of self-disciplinary and lifestyle practices that are given moral weight by their promoters. Even if we accept the 
protestations of many advocates that mindfulness is not a religion per se, it is nonetheless doing the work of religions (Wilson 2014, p. 161).

Part of Wilson's (2014) concern seems to rest around the issue of informed consent. Purser (2015) elaborates on this "camouflage tactic" critique, expressing concern about people who would not accept mindfulness training if they understood its "Buddhist roots" because they "might consider Buddhism incompatible or even a threat to their own religious beliefs" (Purser, p. 26). This objection rests on an assumption, though, that religious beliefs are mutually exclusive and that, in this case, the goal of alleviating (and ultimately reaching the cessation of) suffering is incompatible with other religious goals. It also rests on the assumption that health-care interventions are not value-laden endeavors (Tjeltveit 1999/2005). At any rate, the charge that secular mindfulness programs such as MBSR are disingenuously promoting stealth Buddhism is misconceived. It rests on a certain understanding of religion and Buddhism that does not cohere well with the phenomena they try to describe. Is a person who decides to undertake a light exercise regime being a stealth marathon runner? Or, when they decide to undertake training for a more modest goal, such as climbing up the stairs with less breathlessness, are they somehow demeaning or diluting the goals of marathon running by not fully committing to that discipline? It would be absurd to say so.

By the same token, critiques of secular mindfulness training programs as stealth Buddhism falsely imply that these kinds of practices are identical to a full commitment to the path leading to the complete cessation of suffering described by the Buddha. In his critique, Purser seems to want to have it both ways. He criticizes secular mindfulness for not being faithful enough to traditional Buddhism and, yet at the same time, with his stealth Buddhism critique, implies that it is too Buddhist. It is as though he is berating the trainers teaching a $5 \mathrm{k}$ training program for not offering a marathon training program, but at the same time criticizing them for teaching their unsuspecting trainees stealth marathonism. Similar kinds of critiques are found of methods and practice in complementary and alternative medicine (CAM). For example, Brown (2013) argued that many such practices have their roots in religious traditions, such as Hinduism, Buddhism, and Daoism, and that to recategorize them as nonreligious or generically spiritual raises ethical and legal issues around informed consent, autonomy, and consumer protection. These kinds of critiques essentialize the religious nature of these practices, as if once they are used in such contexts they are always and forever the property of their root tradition. Such critiques also reify the categories of religious (or Buddhist) and secular and present them in binary, oppositional, either/or relationships. This denies the existence of any middle ground, or a continuum, where there can be a cross-fertilization of ideas and practices between traditional and contemporary practices and teachings.

Similarly, claims that secular programs dilute and somehow denigrate the integrity of Buddhist teachings (as implied by the "McMindfulness" critiques, e.g., Purser and Loy 2013) also miss the mark. While it might be the case that there are some secular mindfulness trainings that are weak, ineffective, poorly taught, or lacking ethical integrity, a monolithic critique of all secular trainings, by virtue of the fact that they are secular, is far too sweeping. McMindfulness critiques make an implicit assumption that secular approaches are aimed at the ultimate goal of the cessation of suffering and thus misrepresent the training and commitment required for its attainment, or indeed, promote conduct that is antithetical to the attainment of this goal. Both the stealth Buddhism and the McMindfulness kinds of critique rest on an all or nothing model and on a false assumption that mindfulness practice is either secular or Buddhist, with an uncritical acceptance of these categories. Secular programs are not promising the complete cessation of suffering; they are not claiming to offer the complete transformation in the categories of wisdom, ethics, and mental cultivation to the levels of stream-winnership. Nevertheless, according to the model of the causation of liberation, it is in the nature of things that attention to cultivating skillful qualities in one category of the Eightfold Path supports the positive development of other categories. Mindfulness is one of these categories. At least according to Theravadin thought systems, mindfulness is necessarily wholesome or skillful (kuśala), meaning that it is established in nonattachment, friendliness, and wisdom (Gethin 2015, p. 33). In this sense, mindfulness is transformative insofar as its cultivation supports wisdom and ethical action:

We do not have to make our actions wholesome, so much as always be fully aware and present in them, for it is impossible to be fully aware of and present in actions motivated by greed, hatred and delusion without beginning to see them for what they are-the cause of our own and others' suffering (Gethin 2015, p. 34).

In the same way, when we engage in a fitness program, it positively affects not just one of the dimensions of fitness, for example, increased lung capacity, but also has good effects on the other interconnected parts of our systems, such as better circulation, or improved muscle tone.

Of course, for this analogy to work, the description of mindfulness in Buddhist traditions would need to refer to the same qualities of consciousness being described and advocated for in secular programs. This has been discussed at some length elsewhere, with Buddhist scholars such as Dreyfus (2011) and Gethin (2011) arguing that secular 
constructs of mindfulness are often too minimalist or narrow, focusing on the attention part of mindfulness with insufficient recognition of the discernment aspect (see discussion in Compson 2014). The critique is not that some secular presentations of mindfulness are completely wrong, but that they are incomplete or partial, and ultimately therefore not as effective in transforming the mind from being clouded by greed, hatred, and ignorance to its wholesome condition of nonattachment, friendliness, and wisdom.

An example of this is in the discussion of Kabat-Zinn's (1994) well-known definition of mindfulness as nonjudgmental awareness of the present moment. Buddhist scholars such as Dreyfus (2011), Gethin (2011), and Bodhi (2011) challenged this characterization, because mindfulness does include an element of discernment, recognizing and distinguishing pleasant, painful and neutral experiences, and reactions of aversion or craving toward them. According to an Abhidhammic analysis, the mind is incapable of operating in this mode of mindful discernment while at the same time being in the grip of unwholesome mental states, such as aversion or greed (Olendzki 2011). Mindfulness, a wholesome mind state, thus displaces unwholesome mind states for as long as it is present in consciousness.

Theoretically, Kabat-Zinn's (1994) description of mindfulness as nonjudgmental may be inconsistent with its characterization in Buddhist systems of thought as containing a factor of discernment. However, if we consider the possibility that Kabat-Zinn is giving an operational or functional or even cognitive definition of "doing mindfulness," then nonjudgmental can be understood in a sense of nonreactive, paying attention to our responses to certain stimuli without judging them in a way that is aversive or clinging. The instruction to pay attention nonjudgmentally may help to create the spaciousness between stimulus and response that allows for the arising of wholesome mental states. While in this wholesome mind state, the unwholesome consciousness is displaced or blocked; indeed, the mindfulness is accompanied by 18 other wholesome factors including equanimity, nongreed, and nonhatred: "Mindfulness of unwholesome states is transformative precisely because the unwholesome quality of awareness has been replaced with a wholesome attitude." (Olendzki 2011, p. 65). Just as the Eightfold Path describes a causal law, so the Abhidhamma describes a law of the mind. If the instruction to pay attention nonjudgmentally brings about the required effect by initially mitigating reactivity, then whether one self-identifies as Buddhist or secular, wholesome mind states arise.

Gethin (1992) noted how, in the Pali Canon, the Buddha frames his teachings as not antithetical to other holy ways of life (brahmacariyas), but rather as their completion and fulfillment:

The special teaching of the Buddhas, of which the ariyo atthangiko maggo forms a part, is at the same time not presented as something entirely different or divorced from other brahma-cariya, from lesser paths. On the contrary it is the proper and natural conclusion of the process begun by these other paths which may lead, for example, only as far as rebirth in the world of Brahma... It subsumes these not as mere incidentals or as optional sideroads and diversions, but rather as lesser manifestations of the whole. The ariyo atthangiko maggo is a sum and reflection of all brahma-cariya; it is its true and ultimate conclusion (p. 204).

So-called secular mindfulness programs can be understood on this model; they might be partially effective, but are somehow incomplete if one's ultimate goal is the cessation of suffering. Of course, whether one values or aspires to that ultimate goal is a matter of personal choice.

The following passage from the Pali Canon is particularly interesting in this regard as it demonstrates a take it or leave it attitude attributed to the Buddha:

You may think 'The ascetic Gotama says this in order to get disciples.' But you should not regard it like that. Let him who is your teacher remain your teacher. Or you may think: 'He wants us to abandon our rules.' But you should not regard it like that. Let your rules remain as they are. Or you may think, 'He wants us to abandon our way of life.' But you should not regard it like that. Let your way of life remain as it is. Or you may think: ' $\mathrm{He}$ wants to establish us in the doing of things that according to our teaching are wrong and are considered wrong among us.' But you should not regard it like that. Let those things that you consider wrong continue to be so considered. Or you may think: 'He wants to draw us away from things that according to our teaching are good and are so considered among us.' But you should not regard it like that. Let those things that you consider good continue to be so considered. Nigrodha, I do not speak for any of these reasons.

There are unwholesome things that have not been abandoned, tainted, conducive to rebirth, fearful, productive of painful results in the future, associated with birth, decay and death. It is for the abandonment of these things that I teach Dhamma. If you practise accordingly, these tainted things that make for purification will develop and grow, and you will attain to and dwell, in this very life, by your own insight and realisation, in the fullness of perfected wisdom (D 3.57; Walshe 1995, p. 394).

Our argument here is that critics present a false dilemma; either it's Buddhist mindfulness, or it is secular mindfulness, which is necessarily a corruption of Buddhist traditions with harmful consequences. Instead of this dichotomous view, our understanding of the Eightfold Path suggests that a more 
fitting model is of a continuum, a process of training rooted in the causal structure of reality. Buddhist disciplines offer an advanced training program, but they don't have exclusive rights to the causal lawfulness that makes success in these trainings possible.

\section{The Minimum Requirements for Enlightenment}

As we have seen, Purser (2015) draws attention to passages in the Pali Canon to support his argument that one must be Buddhist to follow the Eightfold Path, insofar as the path is a cultural construction by and for Buddhists. This is an important point and deserves further exploration. A key passage Purser cited in support of his position concerns the minimum requirements for a Noble Disciple, beginning with the first level, the stream-winner. Stream-winners are bound inevitably toward enlightenment, so the description of their qualities and attainments gives a picture of the necessary conditions for attaining eventual liberation from suffering. Common to virtually all descriptions of stream-winners in the Pali Canon is the possession of four elements - three unwavering loyalties or confidences and moral practice. These appear to be prerequisites for attaining the fruit of stream-winning. These four conditions, "if cultivated and made much of, conduce to the realizing of the fruits of stream-winning" (S 5.410; Woodward 1997 , p. 351), and subsequently of the next stages of oncereturning, of never-returning, and of arahatship. It is the first three loyalties that Purser refers to in his critique, and at first glance, they do seem to give the impression that one must be Buddhist in order to attain liberation from suffering. In order to determine the validity of this assessment, let us consider these elements in more detail.

The first of the four elements that one must possess in order to be a stream-winner is "unwavering confidence in the Buddha." This is characterized as the conviction regarding the Buddha that:

He is the Exalted One, an arahat, a perfectly enlightened universal Buddha, endowed with (perfect) knowledge and conduct, happy, a knower of the world, an unsurpassed guide of men who have to be restrained, a teacher of gods and men, a Buddha, an Exalted One (S 5.343; Woodward 1997, p. 297).

Confidence in the Buddha must exist to some degree if one is to follow his teachings — one must have some faith in one's teacher if one is to take notice of what he says, particularly when those teachings are intended to loosen the grip of the deep-seated forces of ignorance and craving which dominate one's perception of reality. Similarly, confidence in the Buddha as "perfect in knowledge and conduct" is emphasized because, as an enlightened being, he represents the embodiment of the practice of his teachings and is thus a testimony to both the efficacy of the teachings he propounds and the possibility of achieving nibbana. The opposite of confidence is doubt, which hinders development toward liberation. Not only is doubt one of the five lower fetters, but it is also one of the five hindrances that can obstruct the development of mindfulness in meditation (Ñānamoli 1995). The stream-winner has abandoned doubt and has full confidence in the Buddha's teachings.

The second, related confidence is in the Buddha's teachings, the Dhamma. It is characterized by the faith that: "The dhamma is well-taught by the Exalted One, of advantage to this life, timeless, open to all, leading onwards (to nibbana), understood for themselves by the wise." The third confidence is in the community of monks and nuns and other fellow practitioners, the sangha. This constitutes the belief that:

Walking righteously is the Exalted One's Order of Disciples, walking uprightly, walking in the right way, walking dutifully is the Exalted One's Order of Disciples; ... Worthy of honor are they, worthy of reverence, worthy of offerings, worthy of salutations with clasped hands, - a field of merit and unsurpassed for the world (S v.343; Woodward 1997, p. 297).

The fourth and final factor required before one can become a stream-winner places emphasis on the moral practice expounded by the Buddha. We will return to this fourth factor shortly. First, though, it is important to address these first three confidences as these are behind Purser's claim that "developing complete trust in the three jewels implies a direct knowledge of, and deep commitment to, the Buddhist teachings" which directly contradicts our claim that "there is no reason in principle why familiarity with explicitly 'Buddhist' teachings are a necessary condition for ... liberation” (Purser 2015, p. 27).

If the Eightfold Path is understood as a description of a cosmic law, though, then this apparent tension dissolves. Confidence or faith in the Buddha, Dhamma, and Sangha begins as provisional - to follow a course of training under the tutelage of a teacher and with the support of a community requires a certain trust or confidence that this course of action will be fruitful in the desired way. When one follows the regimen and finds it to be successful, then faith and confidence grows, becoming less provisional. The reason why a stream-winner has unwavering confidence in the three jewels is because she has found them to work. The description of the nature of reality they provide and the course of training based on this understanding delivers on its promise to transform the elements of the Eightfold Path from their ordinary to their transcendent aspects. The training course is effective; the stream-winner knows this, and therein lies her "unwavering confidence." This complete confidence can be understood as a fruit, not a necessary precondition, for stream-winning. Earlier 
we considered the two categories of Buddha-the samma sambuddha and the pacceka-buddha - where enlightenment is attained without following the teachings or disciplines of an already enlightened being. Whether following somebody else's teaching or not, in order to gain liberation, one must have transformed all of the categories of the Eightfold Path from their ordinary to their ariyan or transcendent aspects. Clearly, although it is advantageous to have the Buddha's guidance on how to fulfill this process, it is possible to do so without hearing the teaching of the Buddha.

In the same way, a marathon runner has to attain a certain level of fitness to attain the feat, whether or not he or she has ever been taught by another person. It is the causal nature of the universe that this is possible. Attaining this feat may indeed be much easier under the tutelage of an experienced guide who has already attained it, but it is not impossible to do it alone.

Rather than entailing faith or confidence, the fourth "limb" of stream-winning requires that one is accomplished in moral conduct: "He is possessed of the moral practice loved by the ariyans [noble ones], conduct unbroken, consistent, spotless, unblemished, giving freedom, propounded by the wise, uncorrupted, conducive to concentration" (S 5.343; Woodward 1997, p. 297). Moral conduct is both a prerequisite and a result of progression along the path. As we have seen, owing to the interrelatedness of different elements of the path to liberation, ethical conduct provides a basis for positive development of other path-elements, such as mindfulness and concentration. Once one has got to a certain level of attainment, then the factors that lead to unskillful moral conduct have been abandoned, and moral conduct occurs automatically. We have already seen that the stream-winner has transcended the need for rules and rituals; he or she is in a natural state of ethical goodness. The fourth limb of streamwinning is different in that rather than entailing faith or confidence, it requires that one is accomplished in moral conduct: "He is possessed of the moral practice loved by the ariyans [noble ones], conduct unbroken, consistent, spotless, unblemished, giving freedom, propounded by the wise, uncorrupted, conducive to concentration." (S 5.343; Woodward 1997, p. 297). Moral conduct is both a condition and a result of progression along the path. As we have seen, owing to the interrelatedness of different elements of the path to liberation, ethical conduct provides a basis for positive development of other path-elements, such as mindfulness and concentration. Once one has got to a certain level of attainment, then the factors that lead to unskillful moral conduct have been abandoned, and moral conduct occurs automatically. We have already seen that the stream-winner has transcended the need for rules and rituals; he or she is in a natural state of ethical goodness. Up until this tipping point, one is developing qualities within the eight factors of the path in their worldly or mundane aspect, but creating a synergistic momentum toward Enlightenment.

\section{Conclusion}

What is particularly important about this for the present discussion is that the synergistic relationship between the factors of the Eightfold Path works both ways; as one's mindfulness increases, so the other factors of the path (including the ethical dimensions) develop; as one's ethical conduct becomes more skillful, so it supports the development of the mental concentration factors, including mindfulness, and also the wisdom to discern the nature of reality, including the three marks of existence of impermanence (anicca), not-self (anatta), and suffering (dukkha). In just the same way, someone engaging in, for example, a well-designed running training program will find that accompanying an improvement in their muscle strength they will find an improvement in cardiopulmonary efficiency because all these systems are interrelated. The best (i.e., most effective) training programs will recognize this interrelatedness and develop the different elements of fitness in concert with each other. While there will be some benefit, for example, on the cardiovascular system by working only on strength training, for example, intentionally working on cardiovascular exercises at the same time will likely lead to better results. Different theories of health and fitness may have different hypotheses about the best combination of exercises, and what counts as the best depends upon one's goals. However, while we might say that theories of fitness are socially constructed, there are ontological constraints that help to establish which are the most effective. In other words, the laws of nature underlying the physical processes relating to fitness are ontologically real, not socially constructed. There are ways of testing empirically the effectiveness of certain claims.

In this paper, we have made the claim that from the perspective of traditional Buddhism, the law of the Eightfold Path can be viewed analogously, affecting not just the physical domain but also the psychological and affective. It is underwritten by the ontologically real nature of the universe. The interdependence of our universe, for example, is not just a socially constructed idea, but an ontological reality. Buddhist traditions argue that one of the causes of $d u k k h a$ is a failure to recognize this nature of reality and to live as though things were different. For example, a philosophical adherence to individualism or atomism, reflected in one's everyday life as selfishness, competitiveness, and a lack of concern for the welfare of other beings is ultimately detrimental to one's own and others' flourishing. This is the case not just in human affairs but on the level of the ecological systems in which humans are nested, too. For example, anthropogenic climate change can be understood in this framework, as a failure to understand and, most importantly, live in sync with the limits of these systems, and the result is deleterious to their, and thus also human, flourishing. What we have argued here is that from the Buddhist perspective, views and conduct that promote virtues such as selflessness and compassion are not true 
or skillful because they are "Buddhist," but because they more correctly align with the nature and structure of reality than approaches which promote selflessness. Buddhist traditions are not unique in promoting these values. Baer (2015) makes very interesting observations in this regard. She cited Petersen and Seligman's (2004) 3-year study of diverse spiritual and philosophical traditions that explicitly identify and address the role of virtues in human flourishing (these included Ancient Greek, Taoist, Confucian, Judeo-Christian, and Islamic traditions). Although none of the accounts of virtues were identical, Petersen and Seligman identified six core virtues and corresponding character strengths recognized as important by every tradition: wisdom, courage, humanity, justice, temperance, and transcendence. They proposed that this convergence might be biologically based insofar as these virtues contribute to the survival of our species. Although the way these values and virtues are understood and expressed may be traditionspecific, then, there are ontological constraints that shape them-for example, that they are effective in promoting flourishing. Baer (2015) argued that positive psychology has adopted many of these virtues and character strengths but expressed and conceptualized them "in the language and methods of positive psychology" (p. 966).

We disagree with Purser (2015) that in making such ontological claims we are committing a category error because they are not amenable or reducible to scientific explanation. First, being "amenable or reducible to scientific explanation" is not the final arbiter of truth; to maintain this is an example of the scientism of which he is apparently (and correctly, in our opinion) wary. For example, the relationship between the brain and mind is not so far reducible to scientific explanation but we do not therefore claim that thoughts are not in some sense real or that they are only cultural artifacts. Second, there are ways of measuring and evaluating certain trainings and programs in terms of their effect on psychological, social, and environmental welfare - to deny this is to dismiss whole swathes of social and psychological science. Despite our many disagreements with Purser, we entirely agree with his claim, following Wallace and Bodhi (2006), that "human flourishing entails a mindfulness practice that is congruent with a way of life that supports one's own and others' genuine happiness" (p. 42). This is consonant with the recognition of our interdependence, an interdependence that was described by the Buddha but not created by him.

In arguing against Purser's (2015) rigid dualism between Buddhism or religion on the one hand, and science or secularism on the other, we maintain that functionally and pragmatically such a division would leave us impoverished. If science and Buddhism are presented as being in entirely different and incommensurable category domains, then there can be no meaningful dialog or fruitful interaction between them. We argue that on the contrary it is precisely such interactions that can be helpful to human and environmental flourishing.
Why cannot social or psychological science (continue to) test the hypothesis that the factors of the Eightfold Path are interrelated? Perhaps the law enforcement official or soldier trained in mindfulness not only does become less reactive or trigger happy, but also more likely to examine and care about ways they may or may not be implicated in oppressive systems and structures? Purser describes this rather dismissively as a Trojan Horse argument and doubts its effectiveness not least because mindfulness training in such contexts may not challenge the "disturbing patterns of collective pathology" ( $\mathrm{p}$. 42) such as myopic individualism.

Is mindfulness training alone sufficient to have a radically transformative effect on such pathologies, or is intentional and explicit ethics training required (as implied by the idea of the interrelatedness of the factors of the Eightfold Path)? Scientific and social scientific fields of inquiry can help us to answer this question by measuring these effects. Baer (2015) provided accounts of various studies of this nature supporting the view that engagement in MBIs encourages increasingly prosocial and values-consistent behavior, and concluded, "it therefore seems unlikely that worksite mindfulness training will encourage passive acquiescence with corporate wrongdoing" (p. 964). Baer ultimately argued that methods of teaching ethics that are based on cross-culturally recognized virtues and/or self-identified values based on empirical research have advantages over explicitly Buddhistbased programs because they may have "stronger theoretical and empirical foundations in psychological science, can be used in a variety of secular settings, and are appropriate for a wide range of clients regardless of their religious or spiritual orientations" (p. 966). To return to our analogy of fitness training, Baer's claim is essentially that explicitly Buddhist approaches might not be the most effective in accomplishing flourishing. This is quite possible - even on Buddhist selfunderstanding, the lawfulness of the universe exists whether there is a Buddha to describe it or not. It is not identical with or the property of Buddhism. In theory, then, it could be more effectively described by another tradition, effectiveness being defined as whether or not the teaching or practice works in alleviating suffering and promoting flourishing. Apparent support for this position can be found in a well-known passage of the Kalama Sutta of the Pali Canon, where the Buddha teaches that Dhamma should be evaluated by no other criterion than its effectiveness in bringing welfare and happiness:

Do not go by oral tradition, by lineage of teaching, by hearsay, by collection of scriptures, by logical reasoning, by inferential reasoning, by reasoned cogitation, by the acceptance of a view after pondering it, by the seeming competence [of a speaker], or because you think: "The ascetic is our guru.' But when you know for yourselves: 'These things are wholesome, these things are blameless; these things are praised by the wise; these 
things, if accepted and undertaken, lead to welfare and happiness,' then you should live in accordance with them." (A1.191; Bodhi 2012, p. 281).

On the other hand, Buddhist traditions (and other religious or philosophical traditions) can and do ask searching questions about the values that underpin our endeavors, the desirability of our collective goals and notions of flourishing and otherwise challenge the fact/value distinction that is often operationally assumed in our scientific fields of inquiry. Just such a point is made by Thanissaro (2012) on the above passage from the Kalama Sutta. He warned against using the quote above to support a "cut and paste" or "do it yourself kit" vision of the Dhamma. He highlighted that in addition to the criterion of whether a practice works in bringing about welfare and happiness is whether the practices are "praised by the wise." He used this to emphasize the model of apprenticeship that is offered by Buddhist traditions - in other words, practicing the Dhamma is a skill, a progressive training, which is generally easier under the mentorship of some person or group that is more experienced in or accomplished in that skill: "When offered the choice, wouldn't you prefer reliable guidance on how to end your suffering rather than a do-ityourself kit with vague instructions and no guarantees?" (Thanissaro 2012, p. 3). One of the dangers he sees in what he described as a postmodern Buddhism, where "no one's interpretation can be criticized as wrong" is that it assumes a clear discernment of what works and implies a kind of relativism. One of the insights from traditional Buddhism is that one's discernment and judgment about what is skillful and unskillful improves as one trains:

But even when judging the results of your own actions, you can't simply take your own ideas of "what works" as a trustworthy standard. After all, you can easily side with your greed, aversion, or delusion, setting your standards too low. So to check against this tendency, the Buddha recommends that you also take into consideration the views of the wise, for you'll never grow until you allow your standards to be challenged by theirs (Thanissaro 2012, p. 1).

This provides a corrective to a quick-fix mentality, stressing the importance of continued practice under the guidance of somebody more accomplished. In our original paper, we argued for a continuing and mutually challenging dialog between traditional and contemporary mindfulness communities. Thanissaro's (2012) comments provide an excellent example of how contemplatives and Buddhist scholars steeped in the practice of the Dhamma provide feedback and checks and balances to the contemporary secular mindfulness, helping to deepen and enrich the dialog. To essentialize mindfulness as a religious, Buddhist practice not only closes the door to such dialog, but it is also to misrepresent the Dhamma taught by the Buddha, which presents the Eightfold Path to the cessation of suffering as his discovery, not his creation, with the law of the Eightfold Path having universal applicability.

Acknowledgments The authors are grateful to Ann Gleig, Ph.D, and Eric Bugyis, Ph.D, for their helpful feedback on earlier drafts of this article and to members of the UW Tacoma faculty writing group for their support and encouragement.

\section{Compliance with Ethical Standards}

Conflict of Interest The authors declare that they have no competing interests.

\section{Abbreviations}
A Anguttara Nikāya
D Digha Nikāya
M Majjhima Nikāya
S Samyutta Nikāya

\section{References}

Amaro, A. (2015). A holistic mindfulness. Mindfulness, 6, 63-73.

Baer, R. (2015). Ethics, values, virtues, and character strengths in mindfulness-based interventions: a psychological science perspective. Mindfulness, 6, 956-969.

Bodhi, B. (2000). The connected discourses of the Buddha: a new translation of the Samyutta Nikāya; translated from the Pāli; original translation by Bhikkhu bodhi. Somerville: Wisdom Publications.

Bodhi, B. (2011). What does mindfulness really mean? A canonical perspective. Contemporary Buddhism, 12(1), 19-39.

Bodhi, B. (2012). The numerical discourses of the Buddha: a translation of the Anguttara Nikāya. Boston: Wisdom Publications.

Brown, C. (2013). The healing Gods: complementary and alternative medicine in Christian America. New York: Oxford University Press.

Cabezón, J. I. (1995). Buddhist studies as a discipline and the role of theory. Journal of the International Association of Buddhist Studies, 18(2), 231-268.

Compson, J. (2014). Meditation, trauma and suffering in silence: raising questions about how meditation is taught and practiced in western contexts in the light of a contemporary trauma resiliency model. Contemporary Buddhism, 15(2), 1-24.

Cullen, M. (2011). Mindfulness-based interventions: an emerging phenomenon. Mindfulness, 2(3), 186-193.

Davis, J. (2015). Facing up to the question of ethics in mindfulness-based interventions. Mindfulness, 6, 46-48.

Dreyfus, G. (2011). Is mindfulness present-centered and non-judgmental? A discussion of the cognitive dimensions of mindfulness. Contemporary Buddhism, 12(1), 45-54.

Gethin, R. M. L. (1992). The Buddhist path to awakening: a study of the bodhi-pakkhiyā dhammāa. Leiden: E.J. Brill.

Gethin, R. M. L. (1998). The foundations of Buddhism. New York: Oxford University Press.

Gethin, R. M. L. (2011). On some definitions of mindfulness. Contemporary Buddhism, 12(1), 263-279. 
Gethin, R. M. L. (2015). Buddhist conceptualizations of mindfulness. In K. W. Brown, J. D. Creswell, \& R. M. Ryan (Eds.), Handbook of mindfulness: theory, research and practice. New York: Guildford.

Gombrich, R. F. (2006). Theravāda Buddhism: a social history from ancient Benares to modern Colombo (2nd ed.). New York: Routledge.

Greenberg, M., \& Mitra, J. (2015). From mindfulness to right mindfulness: the intersection of awareness and ethics. Mindfulness, $6(1)$, 74-78.

Grossman, P. (2015). Mindfulness: awareness informed by an embodied ethic. Mindfulness, 6(1), 17-22.

Jayatilleke, K. N. (1963). Early Buddhist theory of knowledge. London: Allen \& Unwin.

Kabat-Zinn, J. (1994). Wherever you go, there you are: mindfulness meditation in everyday life. New York: Hyperion.

Kabat-Zinn, J. (2013). Retrieved from New York Academy of Sciences. Retrieved from the New York Academy of Sciences. https://www. youtube.com/watch? $\mathrm{v}=\mathrm{c} 0$ dup $-0 \mathrm{Dh} 0 \mathrm{~g}$

Lindahl, J. (2015). Why right mindfulness might not be right for mindfulness. Mindfulness, 6(1), 57-62.

Masuzawa, T. (2005). The invention of world religions. Chicago: University of Chicago Press.

Mikulas, W. (2015). Ethics in Buddhist training. Mindfulness, 6(1), 14-16.

Monteiro, L., Musten, R. F., \& Compson, J. (2015). Traditional and contemporary mindfulness: finding the middle path in the tangle of concerns. Mindfulness, 6(1), 1-13.

Ñānamoli. (1995). The middle length discourses of the Buddha: a new translation of the Majjhima Nikāya. Boston: Wisdom.

Olendzki, A. (2011). The construction of mindfulness. Contemporary Buddhism, 12(1), 55-70.
Purser, R. (2015). Clearing the muddled path of traditional and contemporary mindfulness: a response to Monteiro, Musten, and Compson. Mindfulness, 6, 23-45.

Purser R. \& Loy, D. (2013). Beyond McMindfulness. Huffington Post, 1 July. Available at: http://www.huffingtonpost.com/ron-purser/ beyond-momindfulness_b_3519289.html. Accessed 21 July 2015.

Smith, W. C. (1978). The meaning and end of religion; a new approach to the religious traditions of mankind. New York: Macmillan.

Thanissaro Bhikkhu (2012). Lost in quotation. Tricycle 22:1 Retrieved from http://www.tricycle.com/feature/lost-quotation. Accessed 11 Sept 2015.

Tjeltveit, A. C. (1999/2005). Ethics and values in psychotherapy. New York: Routledge.

Van Gordon, W., Shonin, E., Griffiths, M., \& Singh, N. (2015). There is only one mindfulness: why science and Buddhism need to work together. Mindfulness, 6(1), 49-56.

Wallace, B. A. (2007). Contemplative science: where Buddhism and neuroscience converge. New York: Columbia University Press.

Wallace, A., \& Bodhi, B. (2006). The nature of mindfulness and its role in Buddhist meditation. Accessed from http://shamatha.org/sites/ default/files/Bhikkhu_Bodhi_Correspondence.pdf. Accessed 10 Sept 2015.

Walshe, M. O. (1995). The long discourses of the Buddha: a translation of the Digha Nikāya. Boston: Wisdom.

Wilson, J. (2014). Mindful America: the mutual transformation of Buddhist meditation and American culture. New York: Oxford University Press.

Woodward, F. L. (1997). Book of kindred sayings, vol 5. London: Pali Text Society. 